\title{
Social attributes of the male that incite the violence by intimate partner
}

\author{
Atributos sociais da masculinidade que suscitam a violência por parceiro íntimo \\ Atributos sociales de la masculinidad que suscita la violencia por pareja intima
}

\begin{tabular}{r}
\hline Andrey Ferreira da Silva' \\
ORCID: 0000-0002-1038-7443 \\
Nadirlene Pereira Gomes' \\
ORCID: 0000-0002-6043-3997 \\
Álvaro Pereira' \\
ORCID: 0000-0002-9382-9269 \\
Fernandes de Magalhães' \\
Orcid: 0000-0003-0631-2374 \\
Fernanda Matheus Estrela" \\
Orcid: 0000-0001-7501-6187 \\
Anderson Reis de Sousa' \\
Orcid: 0000-0001-8534-1960 \\
Jordana Brock Carneiro' \\
Orcid: 0000-0002-7496-852X \\
\end{tabular}

'Universidade Federal da Bahia. Salvador, Bahia, Brazil. "Universidade Estadual de Feira de Santana. Feira de Santana, Bahia, Brazil.

How to cite this article: Silva AF, Gomes NP, Pereira A, Magalhães JRF, Estrela FM, Sousa AR, et al. Social attributes of the male that suscept the violence by intimate partner.

Rev Bras Enferm. 2020;73(6):e20190470. doi: http://dx.doi.org/10.1590/0034-7167-2019-0470

Corresponding author:
Andrey Ferreira da Silva
E-mail: silva.andrey1991@hotmail.com
EDITOR IN CHIEF: Antonio José de Almeida Filho
ASSOCIATE EDITOR: Hugo Fernandes

Submission: 06-16-2019

Approval: 02-10-2020

\section{RESUMO}

Objetivo: Analisar os atributos sociais da masculinidade que suscitam a prática da violência conjugal. Método: Utilizou-se como referencial metodológico a História Oral de Vida. Foram realizadas entrevistas com 13 homens em processo criminal por violência conjugal vinculado à segunda Vara de Justiça pela Paz em Casa, do município de Salvador, Bahia, Brasil, nos meses de abril e julho de 2018. Os dados foram organizados segundo análise de conteúdo temática categorial e interpretados à luz do referencial teórico sobre gênero. Resultados: A oralidade masculina revela que a prática da violência conjugal teve relação com os seguintes constructos da masculinidade: domínio sobre a mulher, chefia familiar, provisão do lar e sexualidade exacerbada. Considerações finais: Considerando que alguns atributos sociais da masculinidade suscitam a prática da violência conjugal, faz-se necessária a criação de espaços de reflexão acerca desses comprometimentos.

Descritores: Masculinidade; Violência de Gênero; Comportamento Social; Violência por Parceiro Íntimo; Homens.

\section{ABSTRACT}

Objective: To analyze the social attributes of masculinity that incite the practice of conjugal violence. Method: Oral Life History was used as a methodological reference. Interviews were conducted with 13 men facing criminal proceedings for conjugal violence linked to the $2^{\text {nd }}$ Vara De Justiça pela Paz Em Casa ( $\left({ }^{\text {nd }}\right.$ Court of Justice for Peace at Home), in the municipality of Salvador, Bahia, Brazil, in April and July 2018. The data were organized according to thematic content analysis and interpreted in the light of the theoretical framework on gender. Results: Male orality reveals that the engagement in conjugal violence was related to the following constructs of masculinity: dominance over women, role as head of the family, family provider, and exacerbated sexuality. Final Considerations: Considering that some social attributes of masculinity give rise to engagement in conjugal violence, it is necessary to create spaces for reflection on how they are compromising.

Descriptors: Masculinity; Gender-Based Violence; Social Behavior; Intimate Partner Violence; Men.

\section{RESUMEN}

Objetivo: Evaluar los atributos sociales de la masculinidad que suscita la práctica de la violencia conyugal. Método: Ha sido utilizado como referencial metodológico la Historia Oral de Vida. Han sido realizadas entrevistas, con 13 hombres en proceso criminal por violencia conyugal vinculado a la segunda Jurisdicción de Justicia por la Paz en Casa, del municipio de Salvador, Bahia, Brasil, en los meses de abril y julio de 2018. Los datos han sido organizados según análisis de contenido temático de categoría e interpretados a la luz del referencial teórico sobre género. Resultados: La oralidad masculina revela que la práctica de la violencia conyugal tuvo relación con los siguientes constructores de la masculinidad: dominio sobre la mujer, jefatura familiar, provisión del lar y sexualidad exacerbada. Consideraciones finales: Considerando que algunos atributos sociales de la masculinidad suscita la práctica de la violencia conyugal, se hace necesaria la creación de espacios de reflexión acerca de esos comprometimientos.

Descriptores: Masculinidad; Violencia de Género; Comportamiento Social; Violencia por Pareja Íntima; Hombres. 


\section{INTRODUCTION}

Masculinity can be understood as a set of symbols that structures the ideal identity model for being a man, represented by attributes, functions, values and culturally determined and expected behaviors for people of the male gender ${ }^{(1)}$. Such attributes have been part of the social construction of male identity since childhood, outlining expected and socially legitimate attitudes, such as violent behavior.

Despite the existence of different types of masculinity, the model considered appropriate is grounded on a hegemonic pattern based on patriarchal constructs ${ }^{(2)}$. This model is based on conception such as heterosexuality, virility, emotional distance, honor, being the family provider, courage, strength, assertiveness, competitiveness, among others ${ }^{(3)}$. Such constructs directly influence the way interpersonal relationships are shaped in society and, in general, guide men to preserve themselves in a position of power and domination, whether in political, family, or work environments ${ }^{(4)}$.

As an example, we can think of the characteristics associated with the male provider, a construct perceived as something positive since it gives the male condition greater respect and social prestige and places him in a prominent position, moving him away from marginalization ${ }^{(5)}$. On the other hand, this same attribute can become toxic, placing him in a situation of vulnerability when you prioritize service over self-care ${ }^{(6)}$ or even when you have difficulty getting a job ${ }^{(7)}$.

Another socially valued element is male honor, which is related to the dignity, esteem, and consideration of others, being associated with the social position occupied by men and based on situations considered to be positive, such as paying their debts and keeping promises ${ }^{(8)}$. Despite being considered a virtue, this masculine attribute, until the late 1970s, was commonly used to justify the practice of violence against women, including femicides, by their husbands, ex-husbands, and partners ${ }^{(9)}$, under the argument of "legitimate defense of honor."

It is clear, therefore, that this and other attributes, when used in asymmetric and domination relations, can have repercussions on situations of violence against women. Concerning this phenomenon, it is possible to observe that women from all over the world are susceptible to experiencing violence, with domestic abuse being the most frequent occurrence, especially by spouses. In Brazil, a survey of 749,024 women reveals that approximately one in ten Brazilians has already experienced some type of domestic or family violence, most of the time practiced by their spouse ${ }^{(10)}$. Even in developed countries such as the United States of America (USA), England and Wales, the numbers of conjugal violence are high, demonstrating the indistinct way in which it spreads worldwide ${ }^{(11)}$.

In addition to the violence rates in conjugality, it is also important to note its repercussions on the lives of women, with female homicide being its maximum expression. A study carried out in Turkey revealed that more than $70 \%$ of the female murders analyzed took place in the victim's home and were carried out by his companions ${ }^{(12)}$. In Brazil, 4,645 women were murdered, which represents a rate of 4.5 homicides for every 100 thousand Brazilians in 2016. In ten years, there is a $6.4 \%$ increase in femicide ${ }^{(13)}$.

When it is not lethal, the experience of violence leaves marks on women, such as hematomas, lacerations, bruises, and fractures caused by physical aggression or due to the somatization process ${ }^{(14)}$.
Concerning men, there is a gap in the production of knowledge regarding the impacts of violence experience on their health. Brazilian research revealed that the experience of preventive detention due to conjugal violence triggered male illness, expressed by mental impairment such as sadness, low self-esteem, apathy, and depression; as well as physical damage, such as gastric and sleep pattern changes, headache, tachycardia and hypertension ${ }^{(6)}$.

Considering the magnitude of the problem and that social constructs influence male behavior for such conduct, we considered essential to know which male attributes, used in a toxic way, raise the engagement in conjugal violence. For this, we adopted the following research question: What social attributes of masculinity incite the engagement in conjugal violence.

\section{OBJECTIVE}

Unveiling the social attributes of masculinity that incite the engagement in conjugal violence.

\section{METHODS}

\section{Ethical aspects}

We contacted the research members by phone and invited them to participate in the study, informing about its relevance and objectives, rights to participate or not in the research, as well as to withdraw at any time, and information anonymity and confidentiality. To this end, men were identified using alphanumeric coding (M1, M2 ... M13), using the letter $\mathrm{M}$, followed by numerals characterizing the order of the interviews. Those who agreed to participate signed the free and informed consent form. Thus, the ethical precepts recommended by Resolutions 466/12 and 510/2016, of the National Health Council, were respected. It should be noted that the project was approved by the Research Ethics Committee of the UFBA (Federal University of Bahia) School of Nursing (CEPEE / UFBA).

\section{Theoretical-methodological framework}

Within the theoretical framework of gender, this study was supported by Scott, whose understanding of gender starts from the observation of social relationships and experiences lived throughout history, thus forming a social identity ${ }^{(15)}$.

\section{Type of study}

Qualitative research based on the Oral History of Life method since it refers to the narrative of men's experience in the face of the attributes of their masculinity.

\section{Methodological procedures}

The approach to collaborators was made possible by their participation in Reflective Groups with Men (RGM) developed by researchers (s) linked to the Study Group "Violence, Health, and Quality of Life," at the Nursing School of the Federal University of Bahia. The objective of these groups is to promote educational activities directed at men who respond legally for conjugal violence, aiming to prevent, reduce and suppress domestic violence against women, as proposed by 
Law 11.340/06, known as the Maria da Penha Law. It is noteworthy, therefore, the insertion of the primary researcher in the reflective workshops to approach the participants. There were no conflicts of interest, as this approach is methodologically recommended to deepen the interviews in Oral Life History $(\mathrm{OLH})^{(16)}$.

\section{Study scenario}

The study scenario was the $2^{\text {nd }}$ Vara De Justiça pela Paz Em Casa ( $2^{\text {nd }}$ Court of Justice for Peace at Home), located in the municipality of Salvador, Bahia, Brazil.

\section{Data source}

Thirteen men were intentionally selected, respecting the inclusion criterion: to be facing criminal proceedings for conjugal violence at the referred institution. Those who were absent from two meetings scheduled for data collection were excluded. It is worth mentioning that, by valuing the narratives emanating from the data collection process, the Oral Life History (OLH) allows the delimitation of the number of participants based on the saturation of the contents of the speeches, without the need for a high number of people integrating into the study ${ }^{(16)}$. Besides, the methodological framework adopted values the deepening of memories apprehended throughout narratives, to the detriment of the number of participants.

\section{Data collection and organization}

Data collection took place from April to July 2018, by retrieving the participants' Oral Life History. The semi-structured interview was used, contemplating sociodemographic aspects (age, religion, race/color, education, family income) and the following guiding question: What situations incited the engagement in violence in your marital relationship? It is noteworthy that the dialogue was established through a common, simple, and direct language. The interviews were conducted by the primary researcher individually, with an average duration of 2 hours and 30 minutes, in a location previously agreed with the participant.

\section{Data Analysis}

The methodological steps proposed by Oral History were followed to systematize the interviews. Thus, initially, all recorded oral content was transcribed in full with the support of a text editing program. Then, the textualization was carried out, a phase in which the speech is organized according to the first person singular, excluding unnecessary elements and identifying the central ideas of each narrative, and transcreation, the logical organization of the text ${ }^{(16)}$.

After this process, the material written by the participants was checked, and they signed the letter of assignment. In order to maintain the methodological rigor and scientific validation of the study, the Consolidated Criteria for Reporting Qualitative Research (COREQ) - was met.

After authorization for the use of the textual corpus, we also covered the stages of content analysis of a corpus of life stories, which aims to establish a summation of the different stories. In this way, each life story was analyzed horizontally, so that it is possible to consider it as a single element of information. After that, the categorical organization was carried out, in which we fragment the corpus into different categories based on units of meaning. Thus, each interview is subdivided into themes that, when grouped, form a global theme ${ }^{(17)}$. At the end of these steps, the following thematic categories emerged: "Dominance over women," "role as head of the family," "Family provider," and "Exacerbated sexuality."The interpretation of the data took place in light of the gender references, from the perspective of Scott ${ }^{(15)}$.

\section{RESULTS}

The 13 research participants were aged between 27 and 54 years old, and most of them declared themselves to be black (11), religious (12), having higher education (6), and a family income of two to ten minimum wages (8).

The social attributes of masculinity that incite the engagement in conjugal violence were presented in the following categories.

\section{Dominance over women}

The study also reveals the dominance of men over their partner, who must be controlled and monitored daily, considered as natural behavior violating the right to come and go, freedom to express themselves and relate to others, especially with their friends. The female behavior considered inappropriate by the spouses also incites conjugal violence.

The man must be in control of everything, including where his partner goes and with whom she is. I didn't like that she went out alone, much less with her friends. Everything was a reason for fighting. (M3)

Every time I came home from work, she was at her friends' house, and I didn't like those friendships. [...] they must explain where and with whom they are going out. As a man, I must be informed about everything. This has always been the subject of our discussions. (M4)

\section{Role as head of the family}

The discourse of men, facing criminal proceedings for conjugal violence, emerges for the understanding that the establishment of rules for the home is an inherently masculine behavior. All must obey such rules, and, in the face of their non-observance, men resort to even physical aggression.

The man is the head of the marriage, that is, he is the one who must guide the house, impose rules and everyone must obey so that everything goes as it should [...] when she did not obey my orders, we argued, I cursed her. They need to understand that the last word has to be ours. We must not be contradicted. (M8)

As the man of the house, I had to determine the rules, and they must be followed. When that didn't happen, mainly due to my wife's lack of respect, I had to take action. I started screaming, lost control, and punched and kicked her. (M13) 


\section{Family Provider}

The narratives raise the perception of being a man as the person responsible for providing for the family, which includes house, wife, and children expenses. Such understanding refers to the male belief of the domestic sphere as a space for women, who should not carry out paid work activities, a determination that, when not accepted, generate strife and even physical aggression.

The man has to work to be able to provide for his family. I provided everything for her and my children, so there was no need for her to want to work. [...] we always argued why I thought she should stay at home taking care of our daughter. (M1)

We men have to work and leave nothing lacking. I had my company, and I didn't want her to work. When she began working, we started to argue a lot. [...] leven hit her because of that. I didn't accept it! (M12)

\section{Exacerbated sexuality}

From the perspective of the research participants, the relationship with multiple partners is something that is part of the male instinct, which refers to the popular character of marital betrayal. However, the female attitude, in the face of not accepting infidelity, predisposes the male engagement in violence.

We men have a very strong carnal side: we cannot see a woman that we are already attracted to her. [...] / cheated on my wife several times. She always found out and confronted me about it. Because of that, we always hurt each other physically and verbally. (M6)

I cheated on my partner several times. I even had a child out of wedlock without her knowing anything. When she found out, she fell upon me; I pushed her, and she hit her head on the wall. [...] she had to understand that this is a man thing, that this type of situation is normal. (M10)

\section{DISCUSSION}

The research participants' orality reveals that the domination of the man over the woman, expressed by the control of friendships, the use of the cell phone, and the places frequented by her, presents itself as one of the attributes of masculinity that incite the engagement in violence in conjugal relations. A study carried out in India, which also identified male domination from authoritarian behaviors, from the imposition of rules in the relationship and in the way women should dress, points out about the socio-historical character of such behaviors, based on patriarchy ${ }^{(18)}$. Despite the advances in discussions regarding women's rights from a gender perspective, it is clear that the power of patriarchy still looms, so that female non-submission to spouse's orders makes her vulnerable to conjugal violence.

The attribute of masculine power over feminine is taught from an early age. National and international literature shows that, since childhood, men and women have been instructed in male dominance, such as the power of men over women and their subservience without questioning ${ }^{(19-20)}$. Such learning occurs, for example, when children witness violence between their parents or when they are direct victims of aggression, as pointed out in a study carried out in the USA, which also affirms their tendency to naturalize and reproduce these models in their future relationships ${ }^{(21)}$. Thus, we infer that the normative, controlling, and disciplinary power of men over women is configured as a social construct of masculinity.

Patriarchal society attributes to man the authority not only over the woman but also over the children, which refers to the position of the family head, another construct of masculinity. Another national study also showed control over the education of children and the imposition of norms on the partner's behavior as elements that incite conjugal violence ${ }^{(22)}$. It is worth noting that women who leave the position of subordination, traditionally intended for them, tend to be punished through violent acts, in some cases, even being killed ${ }^{(23)}$. The male understanding presents such domination as one of his roles, controlling his family, including women, through the standardization of rules ${ }^{(24-25)}$. This strategy is used by men to maintain the hierarchical structure that puts them in a position of power ${ }^{(26-27)}$.

Even when women have paid work activities, and they have a superior financial situation than that of their partners, to the point of promoting the livelihood of the home, the role as head of the family usually remains as belonging to the man. This phenomenon may be related to the fact that women understand that this is a strictly male role, idealizing patriarchal family organization ${ }^{(28)}$. This situation is anchored at the social demand for having a male reference at home, a factor culturally presented as a condition for the success of the family. This belief explains the social pressure on women who escape this pattern and lead single-parent families: in addition to fearing that their children will be stereotyped negatively as the result of an unstructured family, they need to account for the responsibilities that are imposed on them and also prove to society that they are capable ${ }^{(29)}$.

In our study, family provision emerged as a construct of masculinity. The support for the family appears in the statements as inherent to the male condition, which is essential and indispensable for reaching and stabilizing this position. From an early age, boys are positively reinforced about work, not only as a means of guaranteeing the maintenance of their personal and family expenses ${ }^{(28)}$ but mainly for the preservation of honor and male power ${ }^{(20)}$.

However, while boys are encouraged to paid work, girls are instructed in household chores ${ }^{(30)}$, concepts also revealed in the participants' testimonies. This social understanding, which is rooted in the construction of masculinity, often makes women vulnerable, exposing them to situations of violence in conjugality $^{(31)}$. This because when the woman decides to break with the hierarchical and unequal system imposed, deciding to perform work activities outside the domestic scope, they are frequently subjected to abuse ${ }^{(32-33)}$.

The stimulation of an exacerbated sexuality had also been introjected as a structuring component of masculinity and impressively expressed in the participants' marital relationship. Men, when perceiving themselves as legitimate to have a libertine relationship with other women, suggest that this behavior is inherent to the masculine ${ }^{(34)}$. Accordingly, a study carried out with men from Cambodia revealed that they perceive marital betrayal as something natural, which is part of their instinct and 
masculinity ${ }^{(35)}$. For many men, marital betrayal is perceived not only as a male instinct, but also as a provider's right, and therefore, extramarital relationships are considered natural ${ }^{(22,36)}$.

Since women are given the place of permissiveness ${ }^{(37)}$, the nonacceptance of marital betrayals catalyzes situations of violence in the conjugal sphere ${ }^{(38)}$. A national survey that listened to 19 women revealed that the partner's infidelity incites conflicts between the couple, as women tend to question such behavior, which generates conjugal violence ${ }^{(36)}$. A study carried out in Spain also found that most cases of conjugal violence are motivated by male betrayal, and when the woman decides to separate, she also begins to suffer threats and even situations of physical violence ${ }^{(39)}$. Thus, when they are betrayed, women are more likely to suffer violence, either because they protest or because they decide to separate, and it is up to them to ensure their protection, only to accept the betrayal without question.

In the face of such social attributes constitutive of masculinity that have repercussions in situations of conjugal violence, spaces for reflections related to the toxic character or not of these attributes and their impacts on the quality of life are needed, not only for men but, above all, for everyone they interact with. North -American study reveals that these types of interventions, although little used, are effective concerning the process of deconstructing toxic behaviors, as they rise in their participants the need to change their conduct in favor of a more equitable society ${ }^{(40)}$. We hope, therefore, to encourage masculinity models whose attributes are based on more proportional relationships, thus contributing to harmonious and respectful conjugal relations.

\section{Study Limitations}

The study has as a limitation the regionality of the collection and the unilateral presentation of the question, only from the male point of view. The results indicate the importance of symmetry in gender relations in order to deconstruct the toxic masculinity model.

\section{Contributions to the health area}

Nursing plays a relevant role in the identification of constructs before the realization of violent acts and in the search for strategies to prevent them since it contributes to the development and coordination of educational actions and is also in a prominent position for establishing links with others social spaces, such as school, through the Health at School Program (Programa Saúde na Escola -PSE), or the legal environment. Thus, it can contribute in both to the creation of spaces for reflection with male individuals, adolescents and adults, about how these constructs compromise inciting the engagement in violence, to stimulate the social deconstruction of gender and allow the construction of proportional relationships in future conjugal bonds and, consequently, prevent conjugal violence.

In addition to these spaces, professional nurses who work in the emergency sectors can, from the knowledge of these attributes that cause violence, identify vulnerabilities and problems in their family and social context. This evidence would allow the implementation of health promotion actions, from referrals to the areas of social service, psychology, and sectors of the network of attention to violence against women, in conjunction with other agencies, such as legal, aiming at the creation of socio-educational strategies for men.

\section{FINAL CONSIDERATIONS}

The Oral History of the participants reveals that the dominance over women, position as head of the family, family provider, and exacerbated sexuality are social attributes of masculinity that incite the engagement in conjugal violence. The speeches expressed such elements as intrinsic and indispensable characteristics of being a man so that any women's insubordination behavior that threatened the maintenance of this model of masculinity was considered a trigger for the practice of violence.

We observe that the concepts and behaviors elucidated in this research reflect the perpetuation of historical principles about what is expected for people of the male gender. This hegemonic pattern of masculinity, in turn, puts men in a position of power and superiority over women, which is responsible for abuses and violence, sometimes lethal, against this public.

\section{FUNDING}

Fundação de Amparo à Pesquisa do Estado da Bahia (FAPESB).

\section{REFERENCES}

1. Navone SL. Norma, integracion y desafio. Representaciones masculinas de varones con discapacidad física. Sex Salud Soc. 2018;(29):75-98. doi: 10.1590/1984-6487.sess.2018.29.04.a

2. Razera J, Mosmann CP, Falcke D. The interface between quality and violence in marital relationships. Paid. 2016;26(63):71-9. doi: 10.1590/1982-43272663201609

3. Saldanha JHS, Lima MAG, Neves RF, Iriart JAB. Construção e desconstrução das identidades masculinas entre trabalhadores metalúrgicos acometidos de LER/DORT. Cad Saude Publica. 2018;34(5). doi: 10.1590/0102-311×00208216

4. Heber A. 'You Thought You Were Superman': violence, victimization and masculinities. Br J Criminol. 2017;57(1):61-78. doi: 10.1093/bjc/ azv117

5. Enriquez E. O trabalho, essência do homem? o que é o trabalho? Cad Psicol Soc Trab. 2014;17(spe1):163. doi: 10.11606/issn.1981-0490. v17ispe1p163-176 
Social attributes of the male that incite the violence by intimate partner

6. Sousa AR, Queiroz AM, Florencio RMS, Portela PP, Fernandes JD, Pereira A. Homens nos serviços de atenção básica à saúde: repercussões da construção social das masculinidades. Rev Baiana Enferm区. 2016;30(3). doi: 10.18471/rbe.v30i3.16054

7. Silva AF, Gomes NP, Estrela FM, Lírio JGS, Lima VLA, Pereira A. Implicações da vivência de prisão preventiva por violência conjugal: narrativas masculinas. Interface Comun Saúde Educ. 2019;23. doi: 10.1590/interface.170958

8. Guerra VM, Scarpati AS, Brasil JA, Livramento AM, Silva CV. Concepções da masculinidade: suas associações com os valores e a honra. Psicol Saber Soc. 2015;4(1). doi: 10.12957/psi.saber.soc.2015.14840

9. Bandeira LM. Violência de gênero: a construção de um campo teórico e de investigação. Soc Estado. 2014;29(2):449-69. doi: 10.12957/psi. saber.soc.2015.14840

10. Congresso Nacional (BR). Observatório da Mulher contra a Violência. Datasenado. Panorama da violência contra as mulheres no Brasil [Internet]. Brasília - DF; 2016[cited 2018 Oct 3]. Available from: https://www12.senado.leg.br/institucional/omv

11. National Center for Injury Prevention and Control. Preventing Intimate Partner Violence. CDC; 2017.

12. Toprak S, Ersoy G. Femicide in Turkey between 2000 and 2010. Stöckl H, editor. PLoS One. 2017 Aug 23;12(8):e0182409. doi: 10.1371/journal pone.0182409

13. Instituto de Pesquisa Econômica Aplicada (IPEA). Forúm Brasileiro de segurança pública. Atlas da Violência 2018. Brasília - DF; 2018.

14. Carneiro JB, Gomes NP, Estrela FM, Santana JD, Mota RS, Erdmann AL. Domestic violence: repercussions for women and children. Esc Anna Nery. 2017[cited 2018 Oct 3];21(4). doi: 10.1590/2177-9465-ean-2016-0346

15. Scott J. Gênero: uma categoria útil de análise histórica. Educ Real [Internet]. 1995 [cited 2019 Jun 16];20(2):71-99. Available from: https:// seer.ufrgs.br/educacaoerealidade/article/view/71721/40667

16. Meihy J, Holanda F. História oral: como fazer, como pensar. 2ed. Contexto; 2014.

17. Poirier J, Valladon C, Raybaut P. Histórias de vida: teoria e prática. Lisboa: Celta; 1999.

18. Reddy R, Sharma AK, Jha M. Hegemonic masculinity or masculine domination. Int J Sociol Soc Policy. 2019;39(3/4):296-310. doi: 10.1108/ IJSSP-08-2018-0133

19. Hundle AK. The Precarious Diasporas of Sikh and Ahmadiyya Generations: violence, memory, and agency. Michael Nijhawan. New York: Palgrave Macmillan, 2016. 289 pp. book review. Am Ethnol. 2018;45(2):302-3. doi: 10.1111/amet.12656

20. Paixão GPN, Pereira A, Gomes NP, Sousa AR, Estrela FM, Silva Filho URP, et al. Naturalization, reciprocity and marks of marital violence: male defendants' perceptions. Rev Bras Enferm. 2018;71(1):178-84. doi: 10.1590/0034-7167-2016-0475

21. Lupu N, Peisakhin L. The legacy of political violence across generations. Am J Pol Sci. 2017;61(4):836-51. doi: 10.1111/ajps.12327

22. Lírio JGS, Pereira Á, Gomes NP, Paixão GPN, Couto TM, Ferreira AS. Elements which precipitate conjugal violence: the discourse of men in criminal prosecution. Rev Esc Enferm USP . 2019;53. doi: 10.1590/s1980-220×2017036203428

23. Davis R. Violência doméstica na Oceania: o pecado da desobediência e a violência da obediência. In: Blyth C, Colgan E, Edwards K, editors. Cultura do estupro, violência de gênero e religião: religião e radicalismo. Cham: Palgrave Macmillan; 2018.

24. Reis SMG, Leite ACAB, Alvarenga WA, Araújo JS, Zago MMF, Nascimento LC. Meta-synthesis about man as a father and caregiver for a hospitalized child. Rev Latino-Am Enfermagem. 2017;25. doi: 10.1590/1518-8345.1850.2922

25. Miedema SS, Yount KM, Chirwa E, Dunkle K, Fulu E. Integrating male sexual diversity into violence prevention efforts with men and boys: evidence from the Asia-Pacific Region. Cult Health Sex;19(2):208-24. doi: 10.1080/13691058.2016.1214747

26. Meneghel SN, Rosa BAR, Ceccon RF, Hirakata VN, Danilevicz IM. Feminicídios: estudo em capitais e municípios brasileiros de grande porte populacional. Cien Saude Colet. 2017;22(9):2963-70. doi: 10.1590/1413-81232017229.22732015

27. Tsuyuki K, Donta B, Dasgupta A, Fleming PJ, Ghule M, Madhusudana B, et al. Masculine gender ideologies, intimate partner violence, and alcohol use increase risk for genital tract infections among men. J Interpers Viol. 2017;088626051770061. doi: 10.1177/0886260517700619

28. Stern E, Heise L, McLean L. The doing and undoing of male household decision-making and economic authority in Rwanda and its implications for gender transformative programming. Cult Health Sex. 2018;20(9):976-91. doi: 10.1080/13691058.2017.1404642

29. Verza F, Sattler MK, Strey MN. Mãe, mulher e chefe de família: perspectivas de gênero na terapia familiar. Pensando Fam [Internet]. 2015 [cited 2019 Jun 16];19(1):45-60. Available from: http://pepsic.bvsalud.org/pdf/penf/v19n1/v19n1a05.pdf

30. James-Hawkins L, Cheong YF, Naved RT, Yount KM. Gender norms, violence in childhood, and men's coercive control in marriage: a multilevel analysis of young men in Bangladesh. Psychol Violence. 2018;8(5):580-95. doi: 10.1037/vio0000152

31. Vyas S, Jansen HAFM. Unequal power relations and partner violence against women in Tanzania: a cross-sectional analysis. BMC Womens Health. 2018;18(1):185. doi: 10.1186/s12905-018-0675-0

32. Echeverria JGM, Oliveira MHB, Erthal RMC. Violência doméstica e trabalho: percepções de mulheres assistidas em um Centro de Atendimento à Mulher. Saúde Debate. 2017;41(spe2):13-24. doi: 10.1590/0103-11042017s202

33. Naved R, Rahman T, Willan S, Jewkes R, Gibbs A. Female garment workers' experiences of violence in their homes and workplaces in Bangladesh: a qualitative study. Soc Sci Med. 2018;196:150-7. doi: 10.1016/j.socscimed.2017.11.040

34. Munsch CL. Her support, his support: money, masculinity, and marital infidelity. Am Sociol Rev. 2015;80(3):469-95. doi: $10.1177 / 0003122415579989$ 
35. Thapa R, Yang Y, Nget M. Perceptions of sexual infidelity in rural Cambodia: a qualitative study of adolescent men. Am J Mens Health. 2019;13(3):155798831984857. doi:10.1177/1557988319848576

36. Paixão GPN, Gomes NP, Diniz NMF, Couto TM, Vianna LAC, Santos SMP. Situations which precipitate conflicts in the conjugal relationship: the women's discourse. Texto Contexto Enferm. 2014;23(4):1041-9. doi: 10.1590/0104-07072014003290013

37. Willis M, Birthrong A, King JS, Nelson-Gray RO, Latzman RD. Are infidelity tolerance and rape myth acceptance related constructs? an association moderated by psychopathy and narcissism. Pers Individ Dif. 2017;117:230-5. doi: 10.1016/j.paid.2017.06.015

38. Boyce S, Zeledón P, Tellez E, Barrington C. Gender-specific jealousy and infidelity norms as sources of sexual health risk and violence among young coupled Nicaraguans. Am J Public Health. 2016;106(4):625-32. doi:10.2105/AJPH.2015.303016

39. Brassiolo P. Domestic violence and divorce law: when divorce threats become credible. J Labor Econ. 2016;34(2):443-77. doi: $10.1086 / 683666$

40. Aaron SM, Beaulaurier RL. The need for new emphasis on batterers intervention programs. Trauma, Viol Abus. 2017;18(4):425-32. doi:10.1177/1524838015622440 